\title{
Addendum to: harmonic and temporal structure of electric organ discharges of the wave-type in Amazonian knifefishes (Gymnotiformes). [Journal of Ethology, 37 (2019), 1-11]
}

\author{
Leo Bernd Kramer ${ }^{1}$
}

Accepted: 18 January 2021

(c) The Author(s) 2021

Most of the great number of gymnotiform fish species from the Amazon near Manaus, Brazil, collected in 1978, could only be determined to the family level following their contemporaneous taxonomy (Kramer et al. 1981). That was also true for the Sternopygidae and Apteronotidae whose electric organ discharges were studied here (Kramer 2019). The whole collection of fish is now housed in the Bavarian State Collection of Zoology (ZSM), Munich, Germany where their taxonomic identity is being studied.

Open Access This article is licensed under a Creative Commons Attribution 4.0 International License, which permits use, sharing, adaptation, distribution and reproduction in any medium or format, as long as you give appropriate credit to the original author(s) and the source, provide a link to the Creative Commons licence, and indicate if changes were made. The images or other third party material in this article are included in the article's Creative Commons licence, unless indicated otherwise in a credit line to the material. If material is not included in the article's Creative Commons licence and your intended use is not permitted by statutory regulation or exceeds the permitted use, you will need to obtain permission directly from the copyright holder. To view a copy of this licence, visit http://creativecommons.org/licenses/by/4.0/.

\section{Reference}

Kramer B, Kirschbaum F, Markl H (1981) Species specificity of electric organ discharges in a sympatric group of gymnotoid fish from Manaus (Amazonas). In: Szabo T, Czéh G (eds) Sensory physiology of aquatic lower vertebrates. Pergamon Press/Akadémiai Kiadó, Budapest, pp 195-219

Publisher's Note Springer Nature remains neutral with regard to jurisdictional claims in published maps and institutional affiliations.
Leo Bernd Kramer

bernd.kramer@ur.de

1 Zoological Institute, University of Regensburg, 93040 Regensburg, Germany 